Archiv für die gesamte Virusforschung 38, 139-142 (1972)

(C) by Springer-Verlag 1972

\title{
Isolation of Tyuleniy Virus from Ticks Ixodes (Ceratixodes) Putus Pick.-Camb. 1878 Collected on Commodore Islands
}

\author{
By
}

\author{
D. K. Lvov, V. I. Chervonski, I. N. Gostinshchikova, A. S. Zemrt, \\ V. L. Gromasherski, Yu. M. Tsyrkin, and O. V. Veselovskaya
}

The D. I. Ivanovsky Institute of Virology, the U.S. S. R. Academy of Medical Sciences; Kamchatka Regional Sanitary-Epidemiological Station, Petropavlovsk, Kamchatskiy, U.S.S.R.

Received October 20, 1971

\begin{abstract}
Summary
Virus strain LEIV-284 Ka was isolated from Ixodes (Ceratixodes) putus tick collected in August, 1970, from Phalacrocorax pelagicus Pallas (pelagic cormorants) on Commodore Islands. The strain was shown to be identical with strains of Tyuleniy virus, a group B arbovirus, recovered in 1969 on Tyuleniy Island, Sea of Okhotsk. On Commodore Islands, hemagghutination inhibiting antibodies for the virus were found in $6 \%$ of the residents, $22 \%$ of fur seals, $24 \%$ of Uria aalge (common murres), $23 \%$ of Lunda cirrhata (tufted puffins) and in $11 \%$ of the Rissa tridactyla (black legged Kittiwakes).
\end{abstract}

\section{Introduction}

Tyuleniy virus was first isolated in the U.S.S.R. in August, 1969, from ticks Ixodes (Ceratixodes) putus Pickard-Cambridge 1878 collected in the nesting grounds of Uria aalge on Tyuleniy island, Sea of Okhotsk (2-5). The same virus was isolated by ClIFFord et al. (6) on the Oregonian coast of the U.S.A.

According to the programme of the national committee for the study of viruses ecologically associated with birds, tick collections were undertaken in summer 1970 on the Commodore islands, Kamchatka region. The present paper reports the data on the isolation of a strain of Tyuleniy virus from Ixodes (Ceratixodes) putus ticks collected at a colony of seabirds on Commodore islands.

\section{Materials and Methods}

Ixodes (Ceratixodes) putus (Pick.-Camb. 1878) ticks were collected in August, 1970, from Phalacrocorax pelagicus Pallas (pelagic cormorants) on a rock adjacent to the Pacific coast of Bering island, Commodore islands, the tundra zone of the subarctic regions. On the rock there were nesting grounds of seabirds, among which Uria aalge 
(common murres) predominated on Bering island. Serum samples were obtained from adult Russian and Aleutian residents, fur seals and from the following species of birds: Uria aalge Pontoppidau (common murres), Lunda cirrhata Pallas (tufted puffins), Rissa tridactyla Linnaeus (blacklegged Kittiwakes); Rissa brevirostris Brush, Phalacrocorax pelagicus Pallas (pelagic cormorants). Isolation of the virus from ticks was attempted in 2-day-old suckling mice.

Identification of the virus isolates was done by hemagglutination inhibition (HI), complement-fixation (CF) and neutralization tests using suckling mice and chick fibroblast tissue cultures. Antigens were prepared by the sucrose-acetone method (1). To remove inhibitors, sera of human beings and of fur seals were treated with kaolin, sera of birds were treated with acetone according to the standard techniques used everywhere.

Sera were tested with antigens prepared from the following group B arboviruses: Tuleniy, West Nile, Japanese encephalitis and tick-borne encephalitis.

\section{Results}

Strain LEIV-284Ka was obtained from a pool of ticks Ixodes (Ceratixodes) putus collected from Phalacrocorax pelagicus Pallas. Reisolation of the strain was made from the primary material stored at $-70^{\circ} \mathrm{C}$ for 1.5 months. The virus agglutinated goose red cells within an optimal $\mathrm{pH}$ range of 6.4 to 6.5 .

Table 1. Results of Identification of the Strain

\begin{tabular}{|c|c|c|c|c|c|c|c|c|c|}
\hline \multirow[b]{3}{*}{ Antigens } & \multicolumn{3}{|l|}{$\begin{array}{l}\text { Sera } \\
\text { HIT } \\
\end{array}$} & \multicolumn{4}{|l|}{ CFT $^{2}$} & \multicolumn{2}{|l|}{ NT } \\
\hline & \multirow{2}{*}{$\begin{array}{l}\text { Group } \\
\text { A }\end{array}$} & \multicolumn{2}{|c|}{ Group B } & \multirow{2}{*}{$\begin{array}{l}\text { Group } \\
\text { A }\end{array}$} & \multicolumn{2}{|c|}{ Group B } & \multirow{2}{*}{$\begin{array}{l}\text { Sakba- } \\
\text { lin }\end{array}$} & \multirow{2}{*}{$\frac{\text { Mice }^{\mathrm{b}}}{\text { Tyuleniy }}$} & \multirow[t]{2}{*}{$\mathrm{TC}^{\mathrm{e}}$} \\
\hline & & $\begin{array}{l}\text { Group } \\
\text { B }\end{array}$ & $\begin{array}{l}\text { Tyule- } \\
\text { niy }\end{array}$ & & $\begin{array}{l}\text { Group } \\
\text { B }\end{array}$ & $\begin{array}{l}\text { Tyule- } \\
\text { niy }\end{array}$ & & & \\
\hline LEIV-284 KA & 0 & 40 & 160 & 0 & 20 & 80 & 0 & 2.0 & 1.9 \\
\hline Tyuleniy $(-6 c)$ & 0 & 20 & 160 & 0 & 20 & 80 & 0 & 2.0 & 2.6 \\
\hline Sakhalin & - & - & -- & 0 & 0 & 0 & 80 & - & \\
\hline
\end{tabular}

a reciprocals of antibody titers.

b $\log$ NI in suckling mice.

c $\log$ NI in chick fibroblast tissue culture.

The serological identification of the isolated strain indicated that it was identical with the prototype strain LEIV-6C of Tyuleniy virus (Table 1). The cultural behaviour of strains $284 \mathrm{Ka}$ and $6 \mathrm{C}$ of Tyuleniy virus also proved to be similar. In chick fibroblast tissue cultures both strains caused cytopathic effects, formed plaques about $2 \mathrm{~mm}$ in diameter and produced hemagglutinins in a titer of $1: 4$ to $1: 8$ in the culture fluid 48 hours post infection. On the basis of these observations it was, therefore, concluded that strain $284 \mathrm{Ka}$ belongs to Tyuleniy virus.

The results of the HI test performed with sera of human beings, fur seals and birds are summarized in Table 2.

Antibodies were found in sera of two adult residents. High titers of antibodies were regularly demonstrated in fur seals, Uria aalge and Lunda cirrhata Pallas. The lack of antibodies in Phalacrocorax pelagicus Pallas appears to be due to the fact that the amount of the material tested was not representative. Three Uria aalge $(9 \%)$ and one Lunda cirrhata Pallas $(4 \%)$ showed high titers of antibodies 
Table 2. Hemagglutination Inhibiting Antibodies for Tyuleniy Virus in the Sera of Human Beings, Fur Seals and Birds Collected on Commodore Islands

\begin{tabular}{|c|c|c|c|c|c|c|c|}
\hline \multirow[b]{4}{*}{ Hosts } & \multicolumn{7}{|c|}{ Sera tested } \\
\hline & \multirow{3}{*}{$\begin{array}{l}\text { Total } \\
\text { No. }\end{array}$} & \multicolumn{6}{|c|}{ Positive } \\
\hline & & \multirow[t]{2}{*}{ No. } & \multirow[t]{2}{*}{$\%$} & \multicolumn{4}{|c|}{ Antibody titres } \\
\hline & & & & $1: 20$ & $1: 40$ & $1: 80$ & $1: 160$ \\
\hline Residents & 33 & 2 & 6 & - & 1 & 1 & - \\
\hline Fur seals & 64 & 14 & 22 & 3 & 6 & 2 & 3 \\
\hline \multicolumn{8}{|l|}{ Birds: } \\
\hline $\begin{array}{l}\text { Common murre } \\
\text { (Uria aalge) }\end{array}$ & 33 & 8 & 24 & 4 & 4 & - & - \\
\hline $\begin{array}{l}\text { Tufted Puffin } \\
\text { (Lunda cirrhata) }\end{array}$ & 26 & 6 & 23 & 2 & 3 & 1 & - \\
\hline $\begin{array}{l}\text { Blacklegged Kittywake } \\
\text { (Rissa tridactyla) }\end{array}$ & 18 & 2 & 11 & 2 & - & - & - \\
\hline $\begin{array}{l}\text { Redlegged Kittywake } \\
\text { (Rissa brevirostris) }\end{array}$ & 6 & 0 & - & - & - & - & - \\
\hline $\begin{array}{l}\text { Pelagic cormorant } \\
\text { (Phalacrocorax pelagicus) }\end{array}$ & 5 & 0 & - & - & - & - & - \\
\hline
\end{tabular}

$(1: 20,1: 40,1: 640)$ for Japanese encephalitis virus, however, they lacked antibodies to other representatives of group $\mathbf{B}$ arboviruses.

\section{Discussion}

The isolation of Tyuleniy virus on Commodore islands along with the isolation of the same virus (Three Arch virus) by CLIFford et al. $(6)$ in the North of the Pacific coast in U.S.A., Oregon, have confirmed the prognoses made earlier $(3-5)$. The predicted geographical distribution of the virus, probably coinciding with that of $I$. putus ticks needs a further investigation.

The results of a serological survey indicated possible infection of man with Tuleniy virus in fact. According to our observation, up to 50 ticks actively attack a human bait during 20 minutes exposure on the breeding territory of seabirds. Serological data also suggest that fur seals along with birds actively participate in the ecological circulation of the virus. The pathogenicity of the virus for man, fur seals and colonial birds, however remains questionable.

\section{Addendum}

The identity of strains of Tyuleniy virus originating from the U.S.S.R. and the U.S.A. (Three Arch virus) was established by Dr. Casals at the World Reference Center for Arboviruses at YARU in January, 1971, by complement-fixation and neutralization tests. In addition, results obtained by complement fixation tests indicated that Tyuleniy virus differed from the following group B arboviruses:

1. Four-fold difference of homologous and heterologous titers with Alfuy, Ilheus, Israel turkey meningoencephalitis, Kadam, tickborne encephalitis and yellow fever viruses. 
2. Eight-fold difference of titers with Apoi, Banzi, Edge Hill, Japanese encephalitis, Langat, Murray Valley, Omsk hemarrhagic fever, Powassan, Tembusu, Usutu, Wesselsbron and West Nile viruses.

3. Sixteen-fold difference of titers with Bussuquara, Central European Tickborne, dengue-4, Kunjin, Louping-ill, Negishi, Ntaya and Spondweni viruses.

4. Negative results $(<1: 8)$ were obtained with Cowbone Ridge, Dakar bat, dengue 1, dengue 2, dengue 3, Egypt Art, Entebbe bat, Tbadan, An 10069, Kokobera, MML, Modoc, Stratford and Zika viruses.

\section{Acknowledgements}

The authors wish to thank Dr. J. Casals and YARU's authorities for identification of the virus.

\section{References}

1. Clarke, D., and J. Casals: Improved methods for hemagglutination and hemagglutination-inhibition with arthropod-borne viruses. Amer. J. trop. Med. Hyg. 7, $561(1958)$.

2. Lvov, D. K., A. A. Timophenva, V. I. Chenvonsky, and V. L. Gromashevsky: Tuleniy virus - a new arbovirus isolated in the basin of Sea of Okhotsk. Vop. Virus. (in Russian) No. 1, p. 128 (1971).

3. Lyov, D. K., A. A. Timophenva, V. L. Gromashevsky, and V. I. Chervonsky: Isolation of arboviruses from Ixodes (Ceratixodes) putus ticks collected at a colony of seabirds on Tuleniy Island, Sea of Okhotsk. Vop. Virus. (in Russian), No, 4, p. 440 $(1970)$.

4. Lvov, D. K., A. A. Trmopheeva, A. D. Lebedev, V. I. Chervonsky, V. L. Gromashevsiy, G. A. Klisenko, G. V. Gostinshchikova, and I. N. Kostriko: Foci of arboviruses in the North of the Far East (Working out of a hypothesis and its experimental check up). Vestnik the U.S.S.R. AMS (in Russian), No. 2, p.52 (1971).

5. Lyov, D. K., A. A. Thmophenva, V. I. Chervonsky, V. L. Gromasheysky, G. A. Kuisenko, G. V. Gostinshehikova, and I. N. Kostyrko: Tuleniy virus - a new Group B arbovirus isolated from Ixodes (Ceratixodes) putus Pick.-Camb. 1878 collected on Tuleniy Island, Sea of Okhotsk. Amer. J. trop. Med. Hyg. 20, 456 (1971).

6. Clifford, C. M., C. E. Junkers, L. A. Thomas, E. R. Easton, and D. Corwin: Isolation of a Group B arbovirus from Ixodes Uricae collected on Three Arch rocks naturial wildlife refuge, Oregon. Amer. J, trop. Med. Hyg. 20, 461 (1971).

Authors' address: Dr. D. K. Lvov, Research Director, Institute of Virology, AMS U.S.S.R., Gamaleya Street 16, Moscow D-98, U.S.S.R. 